Cooper, P. D. \& Bellett, A. J. D. (1959). J. gen. Microbiol. 21, 485-497

\title{
A Transmissible Interfering Component of Vesicular Stomatitis Virus Preparations
}

\author{
BY P. D. COOPER* AND A. J. D. BELLETT $\dagger$ \\ Wright-Fleming Institute of Microbiology, St Mary's Hospital, London, W. 2
}

\begin{abstract}
SUMMARY : Serial (more than two) undiluted passages of vesicular stomatitis virus in chick embryo cell monolayers gave low virus yields (e.g. 10 plaque-forming units (pfu)/cell) compared with dilute passage (e.g. $1000 \mathrm{pfu} / \mathrm{cell}$ ): It was concluded that the low yields resulted from production of a transmissible interfering component since a mixture of undiluted passage with dilute passage virus stocks also gave low yields. Lack of infection of some cells, lack of time for complete growth, genotypic viral change, virus inactivation, poor cultures or media variations were excluded as explanations. Yield increase with inoculum dilution was marked with undiluted passage but not with dilute passage stocks. Multiple infection with live virus (dilute passage stocks) gave high yields, and mixed infection between plaque-forming units and transmissible interfering component $(T)$ was required for interference and for propagation of T. Heat or u.v.-inactivation of live virus did not render it able to interfere (i.e. did not form $T$ ). The interference was mostly exclusion (all-or-none) with some slowing of release, since cells which released plaque-forming units released the normal number. $T$ by itself was not toxic, and those cells which received $T$ but not plaque-forming units in the first cycle of growth were protected from degeneration for several days. Cells which received T and plaque-forming units were killed whether or not they released virus.
\end{abstract}

Routine preparation of vesicular stomatitis virus stocks from chick embryo cell monolayers (Cooper, 1957 $a$ ) sometimes gave apparent virus yields of less than 10 plaque-forming units (pfu)/cell (assuming that all cells in the monolayer released virus), while at other times the apparent yield was $1000 \mathrm{pfu} /$ cell or more. A cytopathic effect was always marked or severe in all cells, when sufficient inoculum virus or time of growth was allowed for all cells to complete their virus release before harvesting. Poor culture conditions, media variations or inactivation of extracellular virus did not account for the low yields.

An incomplete form of the virus might have been responsible, since undiluted or low-dilution tissue-culture fluids were often used as inocula, although one or two undiluted passages usually gave high yields, and yields were in general unaffected by inoculum dilution (Cooper, 1958a). However, these experiments all used high-yield dilute passage stocks, since all low-yield stocks were rejected for experimental purposes. A study of the derivation of both Indiana and New Jersey serotype stocks revealed that low-yield preparations always arose by several serial low-dilution passages of initially high yield dilute passage stocks; this has now been frequently repeated. The present paper demonstrates that vesicular stomatitis virus, although not regarded as

- Present address: Virus Culture Laboratory, M.R.C. Laboratories, Carshalton, Surrey. † Present address: Virus Research Group, M.R.C. Laboratories, Carshalton, Surrey. 
a myxovirus, may yet develop a serially transmissible but non-plaque-forming component which interferes with homologous virus growth; despite some analogies with the incomplete form of influenza virus, however, it cannot yet be regarded as an incomplete form of vesicular stomatitis virus. This is discussed by Bellett \& Cooper (1959).

\section{METHODS}

Preparation and storage of virus stocks and assays were as described by Cooper $(1957 a, 1958 a)$. All assays and virus growth were made in $9 \mathrm{~cm}$. diam. Petri dish monolayers containing $2 \pm 0.5 \times 10^{7}$ chick embryo cells. Unless otherwise specified, the media used were as previously described except that the Earle's saline (ES) $+5 \%(v / v)$ horse serum used for cell and virus growth was supplemented with $5 \mathrm{mg}$. lactalbumin hydrolysate/ml. and $1 \mathrm{mg}$. Difco yeast extract $/ \mathrm{ml}$. This supplemented Earle's saline is meant where 'medium" is subsequently mentioned without qualification. Adsorption of virus by monolayers for virus growth (but not assays) was carried out in the incubator hood described by Cooper $(1958 b)$; cells were resuspended for assay of infective centres as described in the same paper. Stocks are numbered according to serotype and type of passage, e.g. NJ.UP. 6, IND.DP. 25.

\section{RESULTS}

\section{Effect of serial dilute and undiluted passage on virus yield/cell}

Table 1 gives an abstract from the derivation of some fifty virus stocks of Indiana serotype used in experiments described here and elsewhere (Cooper, $1958 a, b)$ and made in London in 1956-7. About twenty-five New Jersey stocks made at the same time, and twelve made in California in 1954-5 and used by Cooper $(1957 a, b, c ; 1958 a)$, had a similar derivation. Despite considerable individual variations in yield, one or two undiluted passages from a high-titre stock rarely gave low titres (particularly when of very dilute passage origin), but serial passage undiluted or at low dilution markedly lowered titres. Titres became high again on dilute passage.

Serial undiluted passage depressed New Jersey more than Indiana titres; one Indiana (Pl. 2, fig. 4) and three New Jersey undiluted passages showed less or no cytopathic effect after prolonged incubation despite the presence of adequate numbers of plaque-forming units. The controls were healthy microscopically, and simultaneous undiluted passage with dilute passage stocks gave good cytopathic effects. The titres were still those to be expected from unadsorbed inoculum, despite considerable thermal inactivation (3 days at $\left.37^{\circ}\right)$. The illustration of cell protection by a low-titred Indiana undiluted passage stock in Pl. 2, fig. 4, is compared with uninfected cells (Pl. 1, figs. 1, 2) and cells infected with an Indiana dilute passage stock (Pl. 2, fig. 3).

Unlike New Jersey virus, complete loss of Indiana virus cytopathic effect was not found on serial undiluted passage. Instead, undiluted passage yields stabilized at about $10 \%$ of the dilute passage yields with occasional increases suggesting reversion (e.g. UP. 40, Table 1). One stock (IND.UP. 15). gave a 


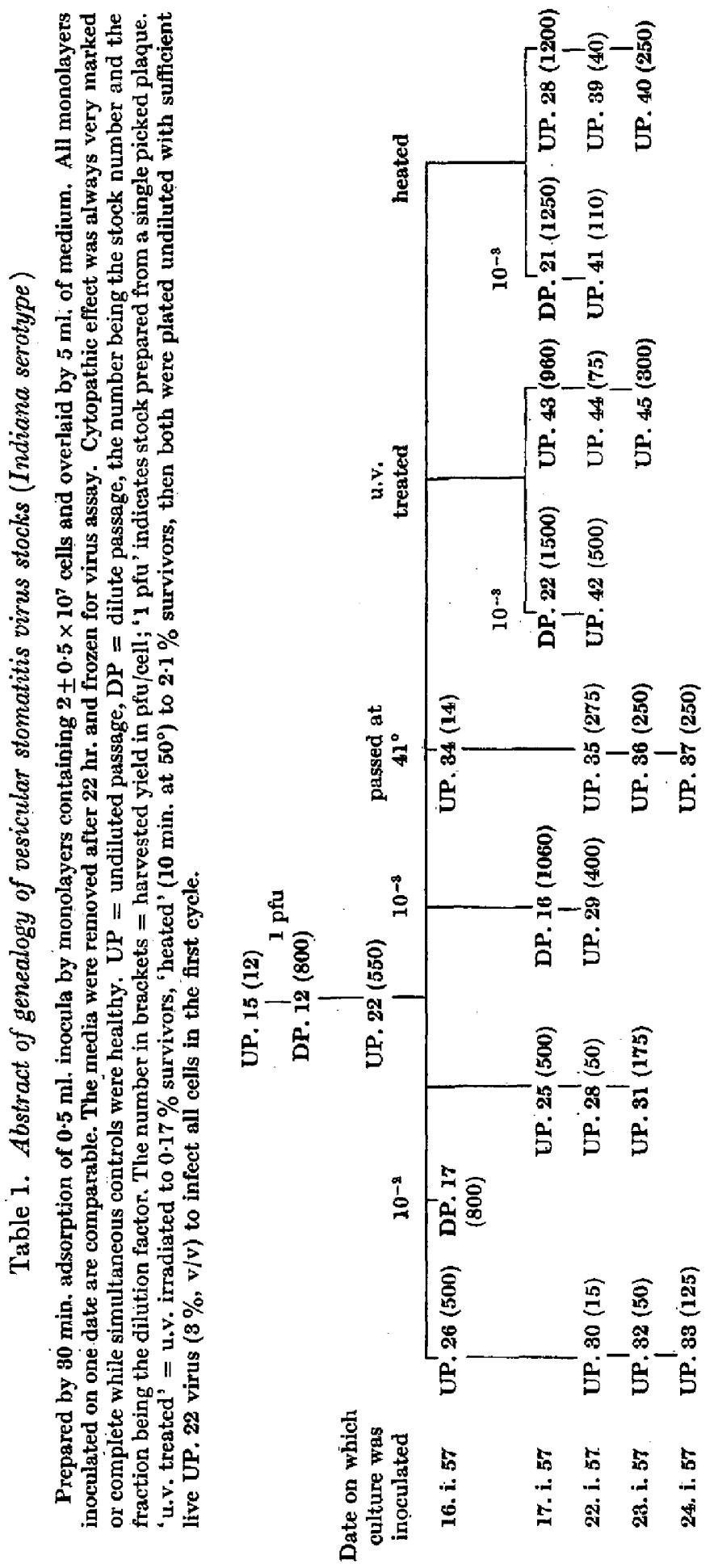


high-titre undiluted passage yield and the same yield on dilute passage (Table 4) strongly suggesting reversion; it was grown at $32^{\circ}$, but this experiment was not repeated.

When the dilute passage and undiluted passage stock titres are grouped without considering their parentage in more detail, the mean titres in $\mathrm{pfu} / \mathrm{ml}$. are: New Jersey, $1.7 \times 10^{9}$ (dilute passage) $1.3 \times 10^{8}$ (undiluted passage); Indiana, $2.7 \times 10^{9}$ (dilute passage) and $6 \times 10^{8}$ (undiluted passage). Thus mean undiluted passage and dilute passage titres differed significantly; since many 'dilute' passages were at low dilution, often from an undiluted passage parent, and some undiluted passage stocks were directly derived from high-titre dilute passage stocks, this significance is enhanced by the need for several serial undiluted passages before the yield was greatly lowered. In fact, if there were an equal number of alternating dilute and undiluted passages one might see no difference.

Factors other than interference which may contribute to a low yield

The existence of interference is postulated later; meanwhile the preceding data, which show low yields with some inocula but not with others, are not significant without considering the system used.

Culture variations. The culture method used (Cooper, 1957 a) usually gave a nearly confluent monolayer with cells partly spread after $20 \mathrm{hr}$. (Pl. 1, fig. 1), becoming fully confluent by $46 \mathrm{hr}$. (Pl. 1, fig. 2) by cell spreading and enlargement rather than by cell division (Cooper, 1957 b). The amount of debris was minimal ; $1-2 \times 10^{7}$ cells were resuspended by trypsin and the microscopical appearance of the cultures was very reproducible. Some non-confluent batches, or individual 'toxic' monolayers, were discarded. Except with very dilute virus inocula, the cytopathic effect at 20-24 hr. after inoculation was always extensive in all cells whether with undiluted or dilute inocula, undiluted or dilute passage stocks or with high or low yields (Pl. 2, fig. 3). Four exceptions to a complete cytopathic effect have been mentioned, and were due to interference. Table 1 compares dilute and undiluted passages in single batches of monolayers, and shows the dependence of yield on the history of the stock. Growth curve studies (Cooper, $1957 a, b, c ; 1958 a$ ) showed that monolayers of one batch released virus very similarly, although some batch-to-batch variation occurred. It is concluded, therefore, that variations in the cultures used did not account for the low yields obtained with certain inocula.

Effect of different media. Apparently identical well-spread monolayers were formed in the medium generally used or in medium ' 199 ' (Morgan, Morton \& Parker, 1950$)+5 \%(\mathrm{v} / \mathrm{v})$ rabbit or horse serum or chick embryo extract. Any of these media, used for monolayer formation or virus release, allowed undiluted passage yields characteristic of stock history and independent of medium.

Inactivation of extracellular virus. The heat lability of vesicular stomatitis virus (half-life 1-2 hr. at $37^{\circ}$ for both serotypes; Fig. 1) will decrease the apparent yields between release and harvesting, but when undiluted passage and dilute passage stocks were compared with the same opportunities for 
thermal inactivation (same multiplicity of infection) the yields were still low and high, respectively. There was no evidence for an increased heat lability on serial undiluted passage, as a permanent change is excluded by obtaining high yields again on one dilute passage (single plaque). Figure 1 shows no marked phenotypic difference between the stabilities of dilute passage and undiluted passage infective components.

Interference by an accumulation of thermally inactivated virus in the stocks

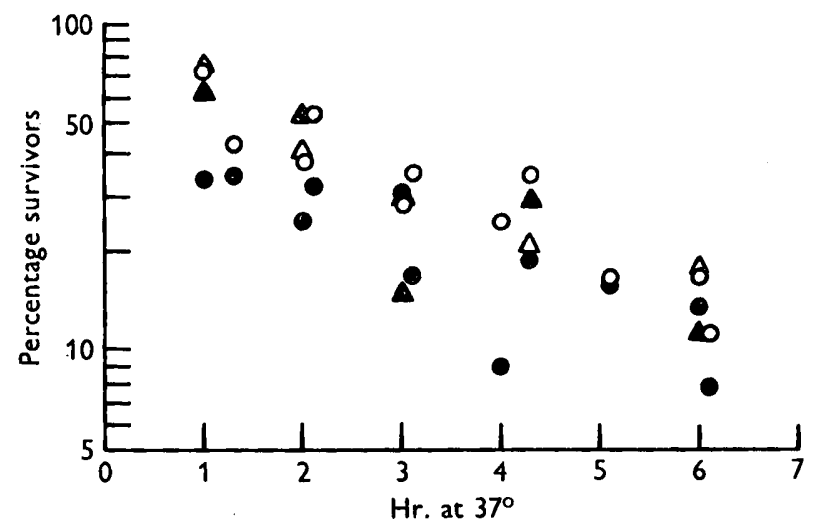

Fig. 1. The stability of vesicular stomatitis virus in medium (supplemented Earle's saline plus $15 \%(\mathrm{v} / \mathrm{v})$ heat-inactivated horse serum) at $37^{\circ}$. Stocks were diluted to about $500 \mathrm{pfu} / \mathrm{ml}$. in warm medium, and samples were taken at intervals and assayed at once for infectivity. The T-containing stocks IND.DP. 6 (O) and NJ.UP. 7 (A) were compared with relatively T-free stocks IND.UP. $22(O)$ and NJ.DP. $10(\triangle)$.

Table 2. The stability of vesicular stomatitis virus in buffer at various $p H$ values and in other media

The buffer solutions ( $M$-citrate in $M$-phosphate) were adjusted to various $\mathrm{pH}$ values with a pH meter and $\mathrm{N}-\mathrm{HCl}$, and autoclaved. A small amount (0.1 ml.) of a New Jersey serotype virus stock of known titre was added to $4 \mathrm{ml}$. medium to give $1.5 \times 10^{6} \mathrm{pfu} / \mathrm{ml}$., and the suspensions were stored at $0^{\circ}$ for $21 \mathrm{hr}$. when they were assayed at once.

\begin{tabular}{|c|c|}
\hline Medium & $\begin{array}{c}\text { Infectivity } \\
\text { remaining } \\
\text { after } 21 \mathrm{hr} \text {. } \\
\text { at } 0^{\circ} . \\
\text { (Percentage } \\
\text { of original) }\end{array}$ \\
\hline Buffer pH 9.1 & 83 \\
\hline $8 \cdot 0$ & 27 \\
\hline $7 \cdot 1$ & 29 \\
\hline $5 \cdot 8$ & 23 \\
\hline 4.9 & 11 \\
\hline $4 \cdot 1$ & $3 \cdot 5$ \\
\hline $\mathbf{3} \cdot \mathbf{0}$ & c. $0 \cdot 1$ \\
\hline $\mathbf{2} \cdot \mathbf{0}$. & $<0.1$ \\
\hline $0.25 \mathrm{~m}$-sucrose & $3 \cdot 9$ \\
\hline $\mathbf{0 . 8 8} \mathrm{M}$-sucrose & $<0.1$ \\
\hline Distilled water & 29 \\
\hline Earle's saline & 49 \\
\hline
\end{tabular}


is not an adequate explanation, since washing the cells after infection during serial undiluted passage did not increase the yield; virus killed by heat, storage at $-2^{\circ}$ or u.v. irradiation does not interfere homotypically (Cooper, 1958b) and did not depress yield when added deliberately (Table 4). Small changes in $\mathrm{pH}$ value or osmotic pressure did not appear to affect infectivity, since the rate of loss of infectivity by vesicular stomatitis virus is the same between $\mathbf{p H} 6$ and 9, although much higher below pH 5 (Table 2); the half-life was similar in distilled water, buffer or Earle's saline (about $10 \mathrm{hr}$. at $0^{\circ}$ ), although much less in sucrose solutions. Undiluted passage gave low yields from undiluted passage stocks and high yields from dilute passage stocks whether or not the serum had previously been heated at $56^{\circ}$ for $30 \mathrm{~min}$. No antibodies fixing complement with undiluted virus stocks were found by Brooksby's (1948) method in the horse serum used, although complement fixation was very good with specific guinea-pig immune sera. Thus, low yields from some inocula but not others cannot be accounted for by extracellular inactivation of virus.

\section{Increasing yield with increasing inoculum dilution with undiluted but not dilute passage stocks}

In a number of experiments, simultaneous comparison of undiluted and dilute passage yields with the same undiluted passage stock and batch of monolayers showed that dilute inocula gave higher yields than the same preparation inoculated undiluted, similar to the effect described by von Magnus (1951) for influenza virus. No difference in yield between undiluted passage or a wide range of dilute passages of New Jersey dilute passage stocks of high titre had previously been found (Cooper, 1957 $a, 1958 a$ ). This suggested that, like influenza virus, the effect of inoculum dilution on yield is more marked with undiluted than with dilute passage stocks. Tables 3-6 confirm the difference between such stocks in the effect on yield of inoculum dilution for both vesicular stomatitis serotypes. Each table represents one experiment with one batch of monolayers; subsequent assays were also performed with a single batch of monolayers.

IND.UP. 22 as dilute passage stock (high titre, one undiluted passage from a high titred dilute passage stock and giving high titres on further undiluted passage) was compared with IND.DP. 6 as undiluted passage stock (low titre, from a long undiluted + low dilution passage series, and giving low titres on further undiluted passage (Tables 3 and 4)). The paradox in nomenclature emphasizes the importance of serial rather than a single undiluted passage (for IND.UP. 22) in inducing this interference, and the inefficacy of one lowdilution passage (for IND.DP. 6) in removing it. IND.UP. 22 showed perhaps a little, while IND.DP. 6 showed a marked, decrease in yield at the two highest concentrations.

The lack of dilution effect with dilute passage New Jersey stocks is shown in Table 5. Table 6 compares two stocks of an undiluted passage series, NJ.DP. 8 (of high titre and giving a fairly high titre on one undiluted passage but derived by one very low dilution (1:2) passage from the original stock) and NJ.UP. 12 (of fairly high titre but giving very low titres on subsequent undiluted passage 
and derived from NJ.DP. 8 by one undiluted passage). Both NJ. DP: 8 and NJ.UP. 12 gave marked dilution effects, but the effect with the later undiluted passage stock was greater than with the earlier, especially at the highest concentrations.

Table 3. The effect of inoculum dilution on $24 \mathrm{hr}$. yields from a serial lowdilution passage Indiana serotype vesicular stomatitis virus stock (IND.DP.6, $8.6 \times 10^{7} \mathrm{pfu} / \mathrm{ml}$.) using monolayers of one batch

The $0.5 \mathrm{ml}$. inocula were removed after $1 \mathrm{hr}$. in the incubator hood, and $5 \mathrm{ml}$. of warm medium were added for virus release at $37^{\circ} . M=$ input multiplicity of infection; cytopathic effect was severe in all cells at harvest

\begin{tabular}{clc}
$\begin{array}{l}\text { Inoculum } \\
\text { dilution }\end{array}$ & \multicolumn{1}{c}{$\begin{array}{c}\text { Yield } \\
\text { pfu/cell }\end{array}$} \\
-Undiluted & $\mathbf{2}$ & $\mathbf{8}$ \\
$1 / 2$ & 1 & 82 \\
$1 / 8$ & $0 \cdot 25$ & $\mathbf{3 1 5}$ \\
$1 / 16$ & 0.12 & 177 \\
$1 / 32$ & 0.06 & 248 \\
$1 / 320$ & 0.006 & 200
\end{tabular}

Table 4. The slight effect of inoculum dilution on $20 \mathrm{hr}$. yield from certain Indiana serotype vesicular stomatitis virus stocks .

The following stocks were compared : a dilute passage stock after one undiluted passage (IND. UP. 22); a serial undiluted passage stock which has reverted to non-auto interference (IND.UP. 15); IND.UP. 22 stocks containing a large excess of either ultraviolet- or heatinactivated Indiana virus. For the latter, some IND.UP. 22 stock was u.v. irradiated to $0.17 \%$ survivors, and some more heated to $2.1 \%$ survivors $\left(10 \mathrm{~min}\right.$. at $\left.50^{\circ}\right)$; sufficient untreated IND.UP. 22 was re-added $(3 \%, v / v)$ to infect all cells in the first cycle on undiluted passage. The inocula $(0.5 \mathrm{ml}$.) were removed from monolayers after $1 \mathrm{hr}$. in the incubator hood, which were washed once with PBS and then given $5 \mathrm{ml}$. of warm medium for virus release at $37^{\circ}$; all monolayers showed complete or severe cytopathic effect at $20 \mathrm{hr}$. $\mathbf{M}=$ multiplicity of infection of live virus; the multiplicity of u.v.- and heat-inactivated virus will be the same as that of live IND.UP. 22.

\begin{tabular}{|c|c|c|c|c|c|c|c|c|}
\hline \multirow[b]{2}{*}{$\begin{array}{l}\text { Inoculum } \\
\text { dilution }\end{array}$} & \multicolumn{2}{|c|}{$\begin{array}{c}\text { IND.UP. } 22 \\
\left(2 \times 10^{9} \mathrm{pfu} / \mathrm{ml} .\right)\end{array}$} & \multicolumn{2}{|c|}{$\begin{array}{c}\text { u.v. treated } \\
\text { IND.UP. } 22 \\
\left(7 \times 10^{7} \mathrm{pfu} / \mathrm{ml} .\right)\end{array}$} & \multicolumn{2}{|c|}{$\begin{array}{c}\text { Heated } \\
\text { IND.UP. } 22 \\
\left(1 \cdot 1 \times 10^{8} \mathrm{pfu} / \mathrm{ml} .\right)\end{array}$} & \multicolumn{2}{|c|}{$\begin{array}{c}\text { IND.UP } 15 \\
\left(5 \times 10^{7} \mathrm{pfu} / \mathrm{ml} .\right)\end{array}$} \\
\hline & $\mathbf{M}$ & $\begin{array}{c}\text { Yield } \\
\text { pfu/cell }\end{array}$ & $\mathbf{M}$ & $\begin{array}{c}\text { Yield } \\
\text { pfu/cell }\end{array}$ & $\mathbf{M}$ & $\begin{array}{c}\text { Yield } \\
\text { pfu/cell }\end{array}$ & $\mathbf{M}$ & $\begin{array}{c}\text { Yield } \\
\text { pfu/cell }\end{array}$ \\
\hline Undiluted & 50 & 500 & 2 & 960 & $2 \cdot 5$ & 1200 & $1 \cdot 2$ & $>500$ \\
\hline $1 / 2$ & 25 & 660 & 1 & 670 & $1 \cdot 2$ & 1500 & 0.6 & 1500 \\
\hline $1 / 4$ & 12 & 840 & 0.5 & 1000 & $0 \cdot 6$ & 1250 & $0 \cdot 3$ & 900 \\
\hline $1 / 10$ & 5 & 1250 & 0.2 & 1110 & 0.25 & 610 & 0.12 & 1250 \\
\hline $1 / 20$ & $2 \cdot 5$ & 1000 & $0 \cdot 1$ & 1000 & $0 \cdot 12$ & 1250 & 0.06 & 960 \\
\hline $1 / 100$ & 0.5 & 1250 & 0.02 & 1500 & 0.025 & 1050 & 0.012 & 1000 \\
\hline $1 / 1000$ & 0.05 & 1060 & 0.002 & 1500 & 0.0025 & 1250 & 0.0012 & 1000 \\
\hline
\end{tabular}

The yield on undiluted passage of dilute passage stocks in presence. of u.v.- and heat-inactivated virus, and at $41^{\circ}$

Addition of u.v.- and heat-inactivated dilute passage stocks to the same untreated dilute passage stock (Table 4) did not cause any depression of yield on one undiluted passage, and further undiluted passage (Table 1) did not suggest that much interfering component had been produced on this passage. 
Table 1 shows that, whereas one undiluted passage at $4 \mathrm{I}^{\circ}$ gave a low yield, further undiluted passage of this low yield stock gave high yields indicating that there had been no accumulation of the interfering component during growth at the higher temperature. It would seem therefore that the interfering component differs fundamentally from heat- or u.v.-inactivated virus.

Table 5. Lack of effect of dilution on $10 \mathrm{hr}$. yield of a dilute passage New Jersey serotype vesicular stomatitis virus stock $\left(9 \cdot 2 \times 10^{8} \mathrm{pfu} / \mathrm{ml}\right.$. $)$

Inocula ( $0.5 \mathrm{ml}$.) were adsorbed for $30 \mathrm{~min}$., the monolayers washed twice with medium and overlaid with $5 \mathrm{ml}$. warm medium for virus release at $37^{\circ}$.

$\begin{array}{lcc}\begin{array}{c}\text { Inoculum } \\ \text { dilution }\end{array} & \begin{array}{c}\text { Multiplicity of } \\ \text { infection }\end{array} & \begin{array}{c}10 \mathrm{hr} \text {. yield } \\ \text { (pfu/cell) }\end{array} \\ \text { Undiluted } & 23 & 180 \\ 1 / 2 & 12 & 220 \\ 1 / 5 & 4 \cdot 5 & 200 \\ 1 / 10 & 2 \cdot 3 & 220 \\ 1 / 20 & 1 \cdot 2 & 180 \\ 1 / 50 & 0 \cdot 45 & 200 \\ 1 / 100 & 0 \cdot 23 & 220 \\ 1 / 200 & 0 \cdot 12 & 115\end{array}$

Table 6. The effect of inoculum dilution on $22 \mathrm{hr}$. yields from two serial lowdilution New Jersey serotype vesicular stomatitis virus stocks, compared using one batch of monolayers

NJ.UP. 12 was derived from NJ.DP. 8 by one undiluted passage. The $0.5 \mathrm{ml}$. inocula were removed after $1 \mathrm{hr}$. in the incubator hood, monolayers were washed once with $5 \mathrm{ml}$. PBS, and $5 \mathrm{ml}$. warm medium added for virus release at $37^{\circ} . M=$ input multiplicity of infection of live virus. Cytopathic effect was severe in all cells at harvest.

\begin{tabular}{|c|c|c|c|c|}
\hline \multirow[b]{2}{*}{$\begin{array}{c}\text { Inoculum } \\
\text { dilution }\end{array}$} & \multicolumn{2}{|c|}{ NJ.DP. $8\left(2.7 \times 10^{9} \mathrm{pfu} / \mathrm{ml}.\right)$} & \multicolumn{2}{|c|}{ NJ.UP. $12\left(1 \times 10^{9} \mathrm{pfu} / \mathrm{ml}.\right)$} \\
\hline & $\mathbf{M}$ & $\begin{array}{c}\text { Yield } \\
\text { (pfu/cell) }\end{array}$ & $\mathbf{M}$ & $\begin{array}{c}\text { Yield } \\
\text { (pfu/ml.) }\end{array}$ \\
\hline Undiluted & 60 & 11 & 25 & 0.90 \\
\hline $1 / 3$ & 20 & c. 20 . & 8 & c. 0.5 \\
\hline $1 / 10$ & 6 & c. 30 & $\mathbf{2 \cdot 5}$ & c. 15 \\
\hline $1 / 30$ & 2 & 65 & 0.8 & 50 \\
\hline $1 / 100$ & 0.6 & 55 & 0.25 & c. 20 \\
\hline $1 / 300$ & - & - & 0.08 & 40 \\
\hline $1 / 1,000$ & 0.06 & 65 & 0.025 & c. 5 \\
\hline $1 / 10,000$ & 0.006 & 180 & 0.0025 & 185 \\
\hline $1 / 100,000$ & 0.0006 & 100 & 0.00025 & 90 \\
\hline
\end{tabular}

Comparative one-step virus release from monolayers infected with dilute or undiluted passage stocks

A comparison of one-step virus release was made between $(a)$ cells completely infected (multiplicity $=6$ ) with dilute passage stocks, and $(b)$ cells with the same multiplicity of infective virus but also with a high multiplicity of the interfering component $T$, which is discussed below.

Figure 2 and Table 7 show one of three such experiments. A high proportion (about $80 \%$ ) of the cells which had received infective virus had nevertheless 
been prevented from releasing infective progeny, so that infective virus was presumed to be 'excluded' by some component of the undiluted passage stock. The other experiments, summarized in Table 8 , show a similar degree of exclusion, and in all three experiments those cells able to release virus did so to an approximately normal yield (84-178\% of controls), as the total yield of the culture was reduced by about the same factor as the number of cells able to release virus. Thus the lowered yield of the undiluted passage

\section{Table 7. Prevention of virus release by the $T$ component}

Of a batch of 20 monolayers of $1.5 \times 10^{7}$ cells, one group of 10 received a dilute passage stock as inoculum (IND.DP. 18, 2.7 $\times 10^{9} \mathrm{pfu} / \mathrm{ml}$. diluted $1 / 10$ in medium to give a multiplicity of infection of 10), and the other group of 10 received an undiluted passage stock (IND.DP. 18 diluted $1 / 10$ in IND.UP. 11, $<5 \times 10^{7} \mathrm{pfu} / \mathrm{ml}$, giving an infective multiplicity $=10$ but with additionally an excess of $T$ ). After $1 \mathrm{hr}$. adsorption at $37^{\circ}$, while still in the incubator hood the inoculum was removed, cells washed once with warm PBS, and $5 \mathrm{ml}$. warm medium were added to each monolayer. After $3 \mathrm{hr}$. infection, cells from 2 monolayers of each group were trypsinized into $1 \mathrm{ml}$. PBS for infective centre assays; the table refers to the composition of this suspension. The supernatant medium was removed from the remaining monolayers, still at $37^{\circ}$, at intervals for virus assay during 1-step growth(see Fig. 2). $A$ and $B$ (col. 1) are duplicates.

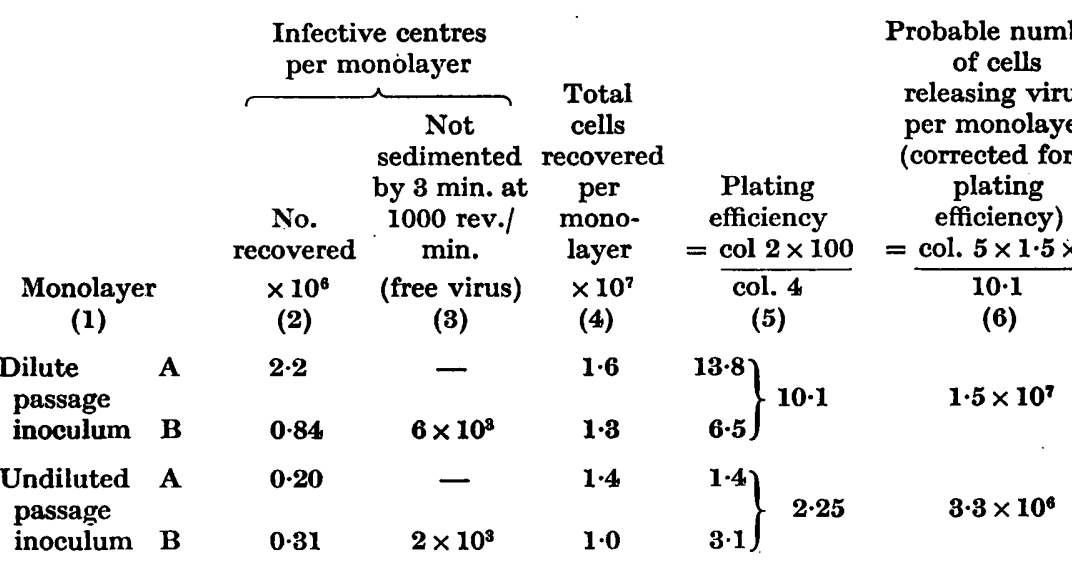

Table 8. Comparison of the plating efficiencies of the infected cell suspensions with final yields during one-step growth of virus from dilute passage (DP) and undiluted passage (UP) stocks

Figure 2 and Table 7 describe expt. 3, and expts. 1 and 2 are duplicates of 3 . Plating efficiency $=$ infective centres $/ \mathrm{ml}$. divided by total cells $/ \mathrm{ml}$.

\begin{tabular}{|c|c|c|c|c|}
\hline $\begin{array}{l}\text { Expt. no. } \\
\text { (1) }\end{array}$ & $\begin{array}{c}\text { Plating } \\
\text { efficiencies of } \\
\text { infected cell } \\
\text { suspensions } 1 \mathrm{hr} \text {. } \\
\text { after infection } \\
\text { (ratio UP:DP) } \\
(2)\end{array}$ & $\begin{array}{c}\text { Time of } \\
\text { harvest of } \\
\text { final yield } \\
\text { (hr. after } \\
\text { infection) } \\
\text { (3) }\end{array}$ & $\begin{array}{c}\text { Final yields } \\
\text { in total } \\
\text { pfu/culture } \\
\text { (ratio UP:DP) } \\
\text { (4) }\end{array}$ & $\begin{array}{c}\text { Yields per } \\
\text { yielding cell } \\
\text { (ratio UP } \\
\text { yield:DP yield } \\
=\text { col. } 4 / \text { col. 2) } \\
\text { (5) }\end{array}$ \\
\hline 1 & 0.200 & 10 & $0 \cdot 168$ & 0.84 \\
\hline 2 & $0 \cdot 105$ & 24 & $0 \cdot 166$ & $1 \cdot 6$ \\
\hline 3 & 0.218 & 24 & $0 \cdot 39$ & $1 \cdot 8$ \\
\hline
\end{tabular}

G. Microb. XXI 
stock is accounted for almost entirely by this exclusion, so that the excluding component is also the yield-reducing component. The latent period of the yielding cells in the interfered cultures was normal in length, although the rate of release was somewhat slowed. Despite the complete prevention of release from most of the cells, cytopathic effect was severe in all cells at $22 \mathrm{hr}$. as in other undiluted passage cultures.

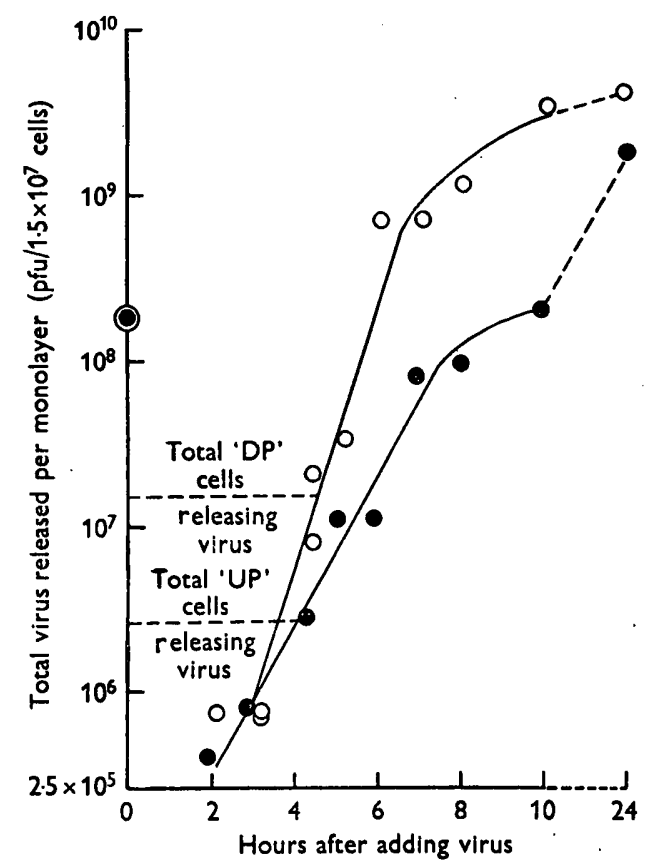

Fig. 2. The effect of the $T$ component on one-step vesicular stomatitis virus release from identical chick embryo cell monolayers. Half of the monolayers received dilute passage virus sufficient to infect all the cells $(O)$, the remainder received the same multiplicity of dilute passage virus with additionally a high multiplicity of $T(O)$; full experimental details are given in Table 7 . The supernatant fluid was removed from one monolayer of each group after various intervals at $37^{\circ}$ and frozen pending assay of pfu. The point on the ordinate represents infective virus initially added, and the broken horizontal lines the number of cells $/ \mathrm{ml}$. able to release virus, corrected for plating efficiency (see Table 7) to give a truer estimate of latent period.

\section{DISCUSSION}

As compared with serial dilute passage, serial undiluted passage of dilute passage vesicular stomatitis virus stocks of either serotype (New.Jersey or Indiana) gave low yields of infective virus, unaccounted for by variations in media, cultures or heat labilities. As a single dilute passage of the lowyielding stock, sometimes from a single plaque, gave high yields again, there must have been no genotypic change in the majority of the virus particles. Multiple adsorption of infective virus alone (dilute passage inocula) did not give low yields, but yields increased with dilution of undiluted passage 
stocks. In some cultures apparent protection of nearly all cells through many viral growth cycles, with no evidence of cytopathic effect and very low yields, resulted from low-titre undiluted passage stocks containing insufficient infective virus to infect all cells initially. A mixture of dilute and undiluted passage stocks infected far less cells than the same dilute passage stock alone. We can only conclude that undiluted passage vesicular stomatitis virus stocks contain a large proportion of a non-plaque-forming component which can interfere with virus growth or release. There is much less in dilute passage seeds, and it is self-duplicating or transmissible in the sense that it stimulates its own formation by infective virus and is not diluted out on successive passage but tends to increase in amount.

The analogy with the familiar 'incomplete' form of influenza virus seems very strong. However, because another type of interfering component exists ('interferon', Isaacs \& Lindenmann, 1957), and because this interfering substance of vesicular stomatitis virus is not yet demonstrably 'virus' in serology and size, it will be called the transmissible interfering component, ' $T$ '. Some relations between $T$, incomplete influenza virus and interferon are discussed by Bellett \& Cooper (1959).

The way in which $\mathbf{T}$ is made remains unknown. Ultraviolet, 'storage' $\left(-20^{\circ}\right)$ and thermal $\left(37^{\circ}\right.$ and $\left.50^{\circ}\right)$ extracellular inactivation of infective vesicular stomatitis virus does not create $\mathrm{T}$; nor does the inactivated virus produce much $T$ when allowed to react with cells; the one passage at $41^{\circ}$ (IND.UP. 34, Table 2) suggests that thermal intracellular inactivation gives similar results. Also the high yields on further undiluted passage of this stock and that stock made at $3^{\circ}$ (IND.UP. 15) suggests that $T$ synthesis is slower than infective virus synthesis at temperatures away from the optimum. $T$ is made only slowly, if at all, in cells not containing infective virus, as otherwise one could not obtain $\mathrm{T}$-free stocks by passage sufficiently diluted to make first-cycle mixed infection between $\mathbf{T}$ and infective virus unlikely, but insufficiently diluted to separate them entirely by end-dilution. This also suggests that $\mathbf{T}$ is not simply a non-cytopathogenic variant of the virus. Placing infective virus on all cells (thereby insuring at least some first-cycle mixed infection between $T$ and infective virus), on the other hand, clearly allows $T$ to be reproduced well. Only a minority of such cells liberates infective virus; which group liberates $\mathrm{T}$ remains unknown.

Regarding the way in which $T$ reduces the yield of a culture, those cells yielding virus release a normal number of plaque-forming units although the release rate may be slower. Very many 'infected' cells cannot release infective virus at all, and exclusion in this sense accounts for nearly all the depression of yield. The widespread cytopathic effect shows that all cells were indeed 'infected', and that the infection, however aborted, is lethal. Exclusion is also shown by the protection of all cells in the three New Jersey low-dilution passages where less than 1 pfu was released per cell, and where cytopathic effect was absent. These indicate that $T$ is not toxic by itself, and suggest that cell breakdown may not occur if enough time is allowed between adsorption of $\mathbf{T}$ and of infective virus. 
Thus interference by $\mathbf{T}$ may take three forms: $(a)$ a slowing of release of infective virus, $(b)$ 'exclusion' (no release) with cell degeneration, (c) exclusion with no cell degeneration. These may conceivably reflect differences in time and quantities of adsorption of $\mathbf{T}$ and plaque-forming units, or different forms of T. The delayed degeneration in Pl. 2, fig. 4 arose with a multiplicity of infective virus of $0 \cdot 3-1$, where for probably half the cells at least $4 \mathrm{hr}$. elapsed between receiving $T$ and infective virus. Cytopathic effect was less delayed for diluted $\left(10^{-3}\right)$ T-free stocks, or for T-containing stocks of higher plaque-forming titre where a much shorter interval would elapse between adsorption of $T$ and of infective virus.

It is interesting that ultraviolet, heat or 'storage' inactivated (and probably live also) dilute passage vesicular stomatitis virus cannot rapidly exclude homotypically (Cooper, 1958b), yet $\mathrm{T}$ can. Among other viruses, one wonders in how many cases of interference by killed or live homologous virus the presence of undetected T-like components can be ruled out.

Because of many genetically 'incomplete' bacterial strains, Burnet (1955) felt that all viruses may exist in some sort of incomplete form, but in its original meaning (von Magnus, 1951) of a transmissible non-cytotoxic interference it is harder to find without a haemagglutinin; reproducible growth and assay systems helped the recognition of $T$ in vesicular stomatitis, in which it is not very obvious. Nevertheless, T-like components may occur among animal viruses other than myxoviruses. Mims (1956) concluded from results similar to the above that the transmissible interfering component of Rift Valley fever was 'incomplete' virus. However, environmental factors complicate in vivo interpretations, and the interfering component may not be the one reacting with or producing specific antibodies, so that as with vesicular stomatitis virus direct evidence of incomplete virus is lacking. Chambers (1957) showed that persistence of western equine encephalomyelitis virus in strain ' $L$ ' cells for many subcultures was due to a transmissible interfering component protecting most cells from cytopathic effect. Dilute inocula caused more cytopathic effect than less dilute, but thermally inactivated virus was not ruled out as the protective agent. On subculture in antiserum, and occasionally spontaneously, virus was lost and the cells became susceptible again, so that lysogeny or genotypic cell resistance seem excluded. Analogous persistence in a continuously growing culture might also be expected with vesicular stomatitis virus because $(a) \mathrm{T}$ can protect most cells from virus, (b) some cells receiving $\mathbf{T}$ and virus can yet release progeny virus, $(c) \mathbf{T}$ can be serially transmitted for many passages. T-like components could well account for instances of persistence in other viruses.

\section{REFERENCES}

Bellett, A. J. D. \& Cooper, P. D. (1959). Some properties of the transmissible interfering component of vesicular stomatitis virus preparations. J. gen. Microbiol. 21, 498.

BrooksBy, J. B. (1948). Vesicular stomatitis and foot-and-mouth disease differentiation by complement fixation. Proc. Soc. exp. Biol., N.Y. 67, 254. 
Journal of General Microbiology, Vol. 21, No. 3
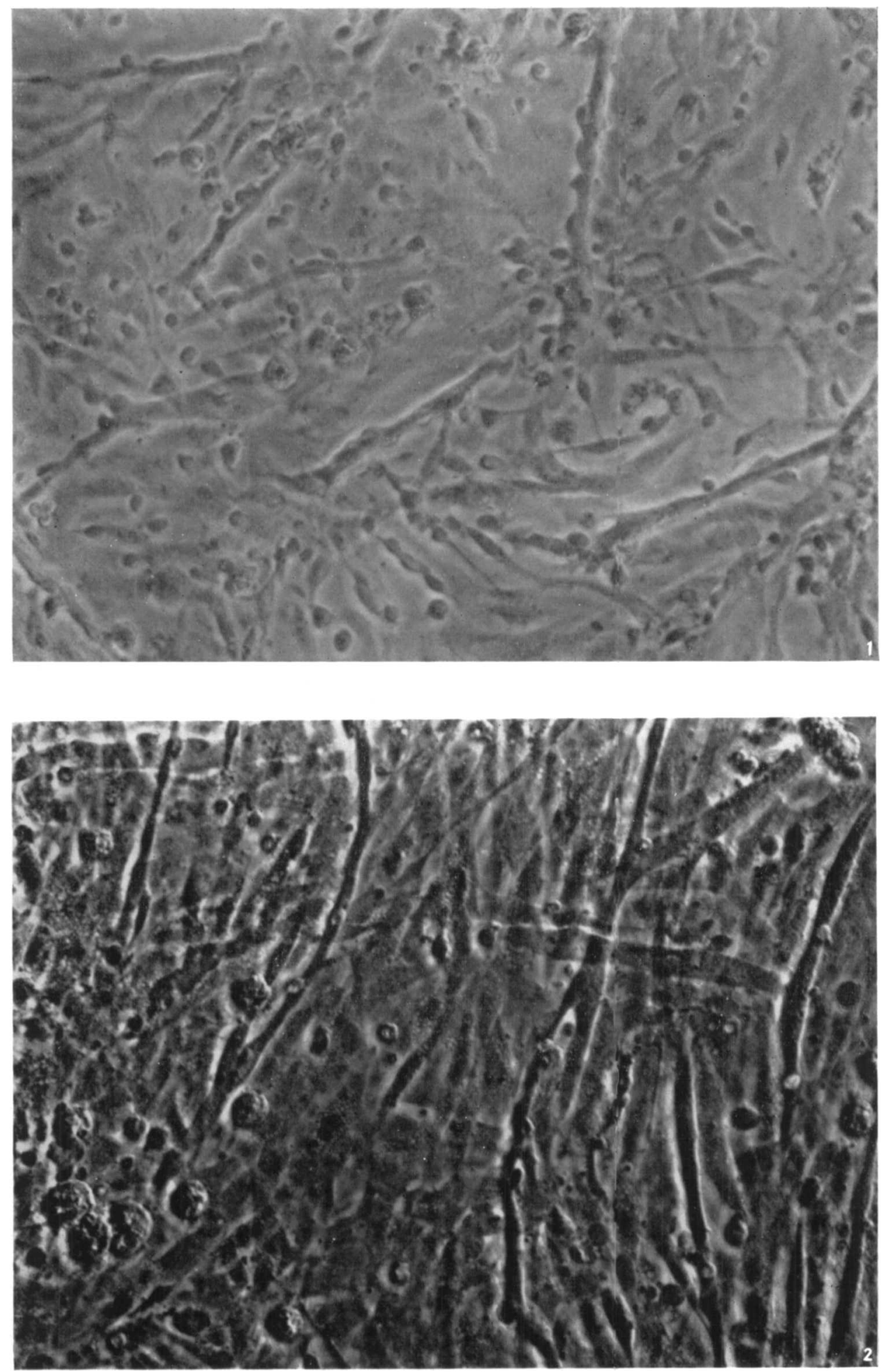

P. D. CoOper \& A. J. D. Belleit -Transmissible interfering component'. Plate 1 
Journal of General Microbiology, Vol. 21, No. 3
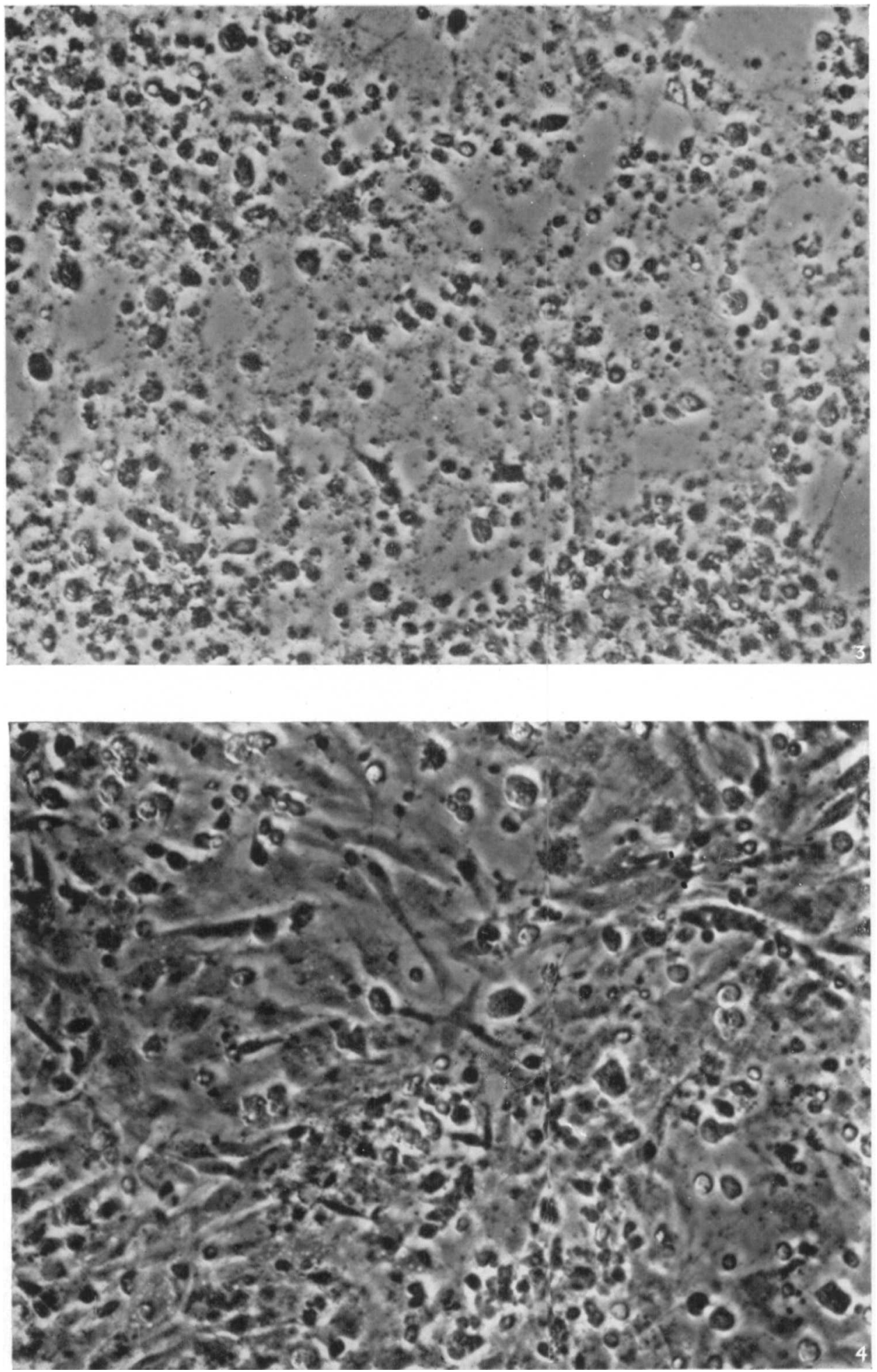

P. D. Cooper \& A. J. D. Bellett-Transmissible interfering component.

Plate 2 
Burnet, F. M. (1955). Principles of Animal Virology, p. 141. New York: Academic Press Inc.

Chambers, V. C. (1957). The prolonged persistence of western equine encephalomyelitis virus in cultures of strain $L$ cells. Virology, 3,62 .

Cooper, P. D. (1957a). Some characteristics of vesicular stomatitis virus growthcurves in tissue culture. J. gen. Microbiol. 17, 327.

Cooper, P. D. (1957b). Paths of phosphate transfer in normal chick embryo cells and in cells infected with vesicular stomatitis virus. J. gen. Microbiol. 17, 335.

Cooper, P. D. (1957c). An osmotic barrier for inorganic phosphate in chick embryo cells and its stability during the latent and release periods of infection by vesicular stomatitis virus. J. gen. Microbiol. 17, 353.

Cooper, P. D. (1958a). ' 'Shortened latency' as a result of multiple infection by vesicular stomatitis virus in chick cell culture. J. gen. Microbiol. 19, 340.

Cooper, P. D. (1958b). Homotypic non-exclusion by vesicular stomatitis virus in chick cell culture. J. gen. Microbiol. 19, 350.

Isaacs, A. \& Lindenmann, J. (1957). Virus interference. . I. The interferon. Proc. roy. Soc. B, 147, 258.

Magnus, P. von (1951). Propagation of the PR 8 strain of influenza virus in chick embryos. 2. The formation of incomplete virus following inoculation of large doses of seed virus. Acta path. microbiol. scand. $28,278$.

Mrms, C. A. (1956). Rift Valley fever virus in mice. IV. Incomplete virus; its production and properties. Brit. J. exp. Path. 37, 129.

Morgan, J. F., Morton, H. J. \& Parker, R. C. (1950). Nutrition of animal cells in tissue culture. I. Initial studies on a synthetic medium. Proc. Soc. exp. Biol., N.Y. 73, 1.

\section{EXPLANATION OF PLATES}

Plates 1, 2, figs. 1-4 are phase-contrast pictures of living unstained chick embryo cell monolayers all of one routine batch, treated simultaneously in a manner identical except for type of inoculum. $\times \mathbf{2 8 0}$.

Pilate 1

Fig. 1. Typical $20 \mathrm{hr}$. monolayer at usual stage of inoculation with virus. Cells are partially spread and nearly confluent.

Fig. 2. Typical $46 \mathrm{hr}$. monolayer, uninoculated. Cells are very well spread and confluent.

Plate 2

Fig. 3. $46 \mathrm{hr}$. monolayer, $26 \mathrm{hr}$. after inoculation with $0.5 \mathrm{ml}$. IND. DP. $18\left(2.7 \times 10^{9} \mathrm{pfu} /\right.$ $\mathrm{ml}$.) and overlaying with $4.5 \mathrm{ml}$. medium. Cytopathic effect is maximal or very extensive in all cells, and many had resuspended from the glass. This effect is typical of most undiluted passage and all dilute passage stocks with inocula undiluted or diluted to $10^{-3}$.

Fig. $4.46 \mathrm{hr}$. monolayer, $26 \mathrm{hr}$. after inoculation with $0.5 \mathrm{ml}$. IND.UP. $11\left(5 \times 10^{7} \mathrm{pfu} / \mathrm{ml}\right.$.). Most cells showed some cytopathic effect being either rounded or with granular cytoplasm but without the extensive degeneration of Fig. 3. The culture had degenerated by $120 \mathrm{hr}$.

(Received 1 April 1959) 